\title{
Diversifikasi Produk Digital Untuk Pengembangan Pasar Tabloid Nova
}

\author{
Dyanasari, R. \\ ${ }^{1}$ Program Studi Ilmu Komunikasi, Universitas Pembangunan Jaya \\ reni.dyanasari@upj.ac.id
}

\begin{abstract}
Media as an organization should build product develop with diversification marketing strategy. Tabloid Nova as one of the biggest woman tabloid in Indonesia is doing diversification strategy by creating online woman tabloid tabloidnova.com. Nova has big opportunities to get successful market development business media. Woman's reader started changing to consume digital media beside of traditional media. Communication Theories that used are media theory, mass media theory, theory of Ansoff Matrix, and Uses and Gratification theory. The research method that used in this research are qualitative method with evaluative approach. This research used three instrument, interview, observation, and literature studies. Analytical techniques used in this research is the method of Huberman and Miles. Resource person were two persons from internal Nova and six external sources of Nova readers. The conclusion from these results showed that the diversification strategy undertaken Nova by building a new medium of digital media tabloidnova.com is quite successful. This is evident by the formation of new markets for digital reader on a product that has not been made before. Visitor numbers also tend to increase every month, so bring the revenue for Nova.
\end{abstract}

Keywords : diversification, marketing, new media

\begin{abstract}
Abstrak : Perusahaan media dapat melakukan pengembangan produk dengan menggunakan strategi marketing diversifikasi. Salah satu diversifikasi yang dilakukan media cetak dalam kasus ini Tabloid Nova adalah dengan membangun tabloidnova.com guna mengembangkan bisnisnya sesuai tuntutan pasar yang diiringi kemajuan teknologi. Hal tersebut penting diperhatikan mengingat tingkat pembaca tabloid mulai berkembang menjadi pembaca digital. Penelitian ini dilakukan untuk menggambarkan peluang keberhasilan pengembangan pasar yang dilakukan Nova, digambarkan dengan menggunakan teori Ansoff Matrix dan Uses and Gratification. Metode yang digunakan dalam penelitian ini kualitatif dengan paradigma konstruktivisme sosial, serta analisis data menggunakan konsep Huberman dan Miles guna menggambarkan data yang spesifik dari pembuat konten media dan pembaca. Data diperoleh dari narasumber internal dan eksternal Nova yaitu manajemen dan pembaca Nova. Hasil penelitian ini menggambarkan bahwa strategi diversifikasi yang dilakukan Nova dengan membangun media baru tabloidnova.com dapat dikatakan berhasil. Hal tersebut terlihat dengan terbentuknya target pasar baru yakni pembaca digital pada produk yang tidak ada sebelumnya. Angka visitor tabloidnova.com cenderung meningkat setiap bulannya dan mampu mendatangkan revenue bagi Nova.
\end{abstract}

Kata Kunci : Diversifikasi, Marketing, Media Baru

\section{PENDAHULUAN \\ Latar Belakang}

Menurut Rivers et al (2003), komunikasi massa dapat diartikan dalam dua cara, yakni, pertama, komunikasi oleh media, dan kedua, komunikasi untuk massa. Namun ini tidak berarti komunikasi massa adalah komunikasi untuk setiap orang. Media tetap cenderung memilih khalayak, dan demikian pula sebaliknya khalayak, dan demikian pula sebaliknya khalayak pun memilih-milih media. 
Namun sebagai khalayak kita harus pintar dan cermat dalam memilih berita yang terdapat di media massa, karena tidak sedikit berita-berita yang bersifat rumor atau hanya issue belaka. Seperti yang dijelaskan pada teori agenda setting bahwa gambaran efek jenis komunikasi dari serangkaian hubungan yang kuat antara isi berita seperti khayalan, konstruksi projek yang belum selesai, dan isu publik yang menonjol atau kepentingan yang ditempatkan pada isu-isu tertentu Bryant (2002). Oleh karena itu media mampu mengarahkan opini publik sesuai keinginan yang telah diatur sebelumnya.

Target pasar setiap media tentunya berbeda, tergantung dari siapa yang akan memaknai pesan tersebut tergantung dimanakah posisi pembacanya. Untuk dapat menentukan target pasar sebuah media, tentunya produk (media) tersebut harus memiliki positioning yang jelas. Positioning adalah tindakan merancang penawaran citra perusahaan sehingga menempati suatu produk kompetitif yang berarti dan berbeda dalam benak pelanggan sasarannya. (http://jurnal.pdii.lipi.go.id/admin/jurnal/1 3208268273.pdf, diakses 6 September 2011, pukul 21.37). Ketika positioning sebuah produk telah jelas, dalam hal ini produk media, makan akan terbentuk pula profil pembacanya. Ketika pesan tersebut hendak disampaikan pada kalangan menengah kebawah dengan latar belakang pendidikan yang rendah, pesan akan dikemas singkat dan memiliki tata bahasa yang sesuai dengan karakteristik pembacanya. Selain pesan, jenis media juga mempengaruhi minat dan pemahaman pembaca terhadap suatu berita.

$$
\text { Menurut McLuhan }
$$
penyampaian pesan dan segala macam hal yang bersifat informasi membutuhkan media. Sebut saja media yang ada sekarang adalah televisi, koran, majalah, radio, bahkan internet. Seperti yang disebut Marshall McLuhan dalam bukunya Understanding Media bahwa media komunikasi modern yang memungkinkan jutaan umat manusia di seluruh dunia dapat berhubungan dengan erat hampir disetiap tempat di dunia. Informasi yang ada sekarang ini juga cukup beragam, mulai dari informasi tentang teknologi, kesehatan, gaya, kecantikan, otomotif, masakan, bisnis, keuangan, dan lain-lain. Masyarakat dapat memperoleh informasi sesuai kebutuhan mereka melalui media massa.

Media Internet saat ini sedang menjadi pilihan banyak orang di Indonesia. Media ini memiliki kelebihan yang tidak dimiliki oleh media-media sebelumnya yang telah ada di Indonesia. Hanya melalui satu media Internet, manusia dapat memperoleh gabungan Informasi dari media yang cetak dan elektronik yang sudah berkembang pesat di zaman keemasannya. Internet dapat menampilkan teks, gambar, bahkan audio visual. Keunikan media ini membuat banyak pihak tertarik untuk mempelajarinya bahkan rutin mengkonsumsinya seperti kebiasan orang membaca koran di pagi hari yang menjadi habbit sebagian besar masyarakat Indonesia.

Negara berkembang seperti Indonesia, menjadi peluang yang besar untuk sebuah media berkembang, begitu pula internet. Masyarakat Indonesia mau menerima perubahan, dan ingin memperdalam mengenai sesuatu yang baru. Oleh karena itu masuknya media baru tidak dapat dibendung peminatnya, sehingga dari tahun ke tahun menunjukan peningkatan yang begitu besar.

Begitu besar peminat media ini, hingga para wanita pun, ingin mengenal media ini. Internet digunakan di perkantoran sehingga para pria yang mayoritas bekerja sangat aktif menggunakan media internet. Namun tidak dapat dipungkiri karena secara psikologis wanita juga memiliki kebutuhan akan informasi secara cepat dan mudah, media yang mudah dan cepat untuk di akses tentu akan menjadi pilihan yang menggiurkan bagi para wanita, baik wanita yang bekerja maupun tidak bekerja. 
Tentu menjadi hal yang menarik untuk diketahui apa saja yang dikerjakan perempuan ketika sedang berinternet tersebut dan apa pula yang dilakukan lakilaki. Ternyata apa yang menjadi favorit perempuan dan laki-laki sewaktu berselancar atau menggunakan internet berbeda. Dari data tersebut, 16,3\% perempuan menggunakan waktu di internet untuk ber-social networking, sedangkan laki-laki hanya $11,7 \%$. Indeks yang ada di samping angka persentase tersebut di atas menunjukkan besarnya waktu yang digunakan, dengan semakin besar indeks, waktu yang digunakan untuk suatu kegiatan tertentu dalam berinternet semakin besar.

(http://tekno.kompas.com/read/2011/01/23 112503713/Perempuan.Lebih.Dominan.di.I nternet diakses 3 July 2011 pukul 21.56)

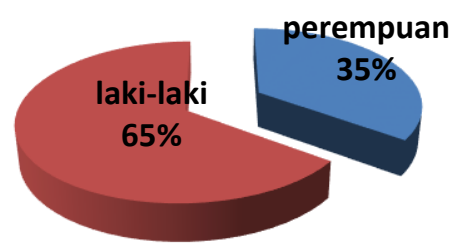

Gambar 1. Pengguna Internet di Indonesia Berdasarkan Jenis Kelamin

Fenomena lain yang berkembang adalah para pengguna internet wanita menggunakan handphone atau perangkat yang dapat dibawa secara mudah lainnya, untung membuka situs internet. Menurut laporan mutakhir 'The State of Mobile $W e b^{\prime}$ yang dilansir oleh Opera Software, ternyata sejak dua tahun lalu pengguna internet mobile kaum Hawa meningkat 575 persen.

(http://hileud.com/hileudnews?title=Opera $\% 3 \mathrm{~A}+$ Pengguna+Internet+Mobile+Wanita + Naik\&id=271466 diakses 20 July pukul 09.03). Dapat terlihat bahwa alat yang digunakan untuk memperoleh internet sudah tak terbatas. Hal ini memungkinkan angka para wanita yang mengkonsumsi internet akan terus naik bahkan mengimbangi para pria. Oleh karena itu peluang bisnis untuk media wanita sudah dapat mengalihkan kontennya untuk di kembangkan melalui media internet. Sejauh ini media digital wanita sudah mulai bermunculan. Mereka melengkapi fiturnya dengan versi mobile, agar lebih mudah di akses dari telepon genggam. Oleh karena peluang media di internet cukup besar, sudah saatnya media-media di Indonesia mempersiapkan media digital lebih matang.

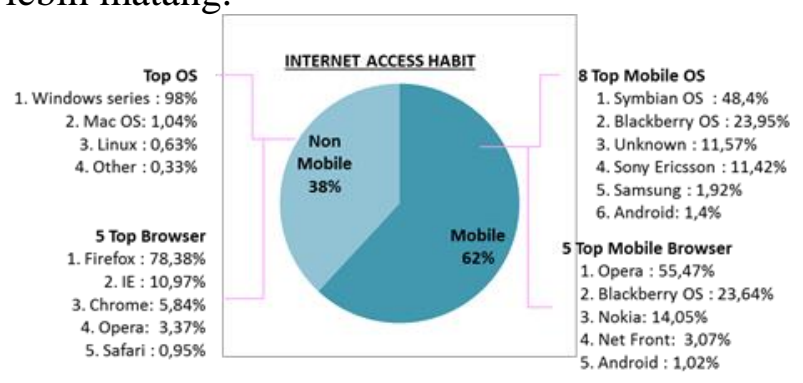

Gambar 2. Pengguna Internet di Indonesia Berdasarkan Perangkat (Sumber: redaksi Nova)

Dikutip dari vivanews.com, Dibandingkan dengan negara-negara Asia Tenggara lainnya, Indonesia ternyata memiliki keunikan tersendiri. Pasalnya, pengguna Internet di sini mayoritas mengakses melalui ponsel (http://teknologi.vivanews.com/news/read/ 212654-mayoritas-netter-indonesia-aksesvia-ponsel diakses 10 Juy 2011 pukul 20.34). Bisnis di melalui perangkat mobile juga patut diperhitungkan. Menjamurnya ponsel pintar membuat masyarakat Indonesia sering mengakses via internet mobile. Aplikasi untuk mobile dan website versi mobile dapat mempermudah pembaca yang menggunakan perangkat mobile untuk mengaksesnya.

Elwin Siregar selaku Publishing General Manager Group of Magazine, Kompas Gramedia menjelaskan dalam artikel dalam Media Guide 2010 yang berjudul To Go or Not To Go Online bahwa;

The digital world has made the information spread in a very fast. 
No boundary of space and time. Even now, everybody can easily becomes a publisher and at the same time becomes the audience because of digital social media.

The keyword here is "everybody". Result of a survey disclosed that there are 40 million people in Indonesia access the Internet. Plus, there are 165 million people who own mobile phone (and around $10 \%$ of them have the internet access).

Another survey revealed that Indonesia is second after Russia for Opera Mini users (a browser softwere for mobilephone). Last February, the Bahasa Indonesia version of Opera Mini has been launched to attact more users in Indonesia using the browser to surf the net. For a comparison, America is at the $7^{\text {th }}$ rank. Indonesia is also mentioned as in the top 5 users of Facebook and Twitter.

Readers of print media have now had an option to find their required information. Some of them, for sure, are readers or potential readers of Gramedia Magazine ( a publisher of more than 50 magazines/ tabloids that has 25\% marketshare in Indonesia).

Tabloidnova.com memberikan konten-konten khas nova seperti rubrik keluarga, kecantikan, kuliner, kesehatan, karier, griya, busana, akan menemani pembacanya setiap hari, lengkap dengan segala problematika dan solusinya. Tabloidnova.com juga menyajikan kabar terbaru seputar selebritis, profil orangorang sukses, berbagai tips menarik, serta peristiwa yang terjadi di sekitar kita. Hingga maret 2011, jumlah page views tabloidnova.com mencapai angka 9,000,000 orang.

Perkembangan media-media cetak lainnya, membuat sebagian pembaca Nova menduplikasikan media dengan tabloid atau majalah wanita lain, yaitu KARTINI, NYATA, FEMINA, atau SEKAR. Walaupun sifat duplikasinya hanya sebagai komplementer, tetapi sebagai pengingat, diantara majalah/tabloid lain, angka NYATA sebagai substitusi NOVA relatif lebih tinggi. Oleh karena itu Nova harus mampu bersaing dengan para kompetitornya, bahkan sebisa mungkin menghindari duplikasi media yang dilakukan pembaca, karena ketika itu dilakukan, pembaca masih belum merasa kebutuhannya terpenuhi hanya dengan membaca Nova. Alangkah lebih baiknya Nova mampu mengakomidir keseluruhan kebutuhan pembaca, salah satunya dengan pengembangan dari produk Nova yang suadah ada sekarang.

\section{Rumusan Masalah}

"Adakah peluang keberhasilan produk digital untuk pengembangan pasar tabloid nova?"

\section{Tujuan} antara lain:

Tujuan penelitian yang dilakukan

1. Untuk menganalisis kebutuhan pembaca akan keberadaan media digital sebagai segmen baru tabloid Nova guna memfokuskan strategi Nova.

2. Untuk mengetahui strategi yang dilakukan untuk memperoleh pembaca digital.

3. Untuk mengetahui peluang keberhasilan dari pengembangan pasar tabloid Nova.

\section{Sistematika Penulisan}

\section{Latar Belakang}

Penjelasan tentang latar belakang masalah, perumusan masalah, tujuan penelitian, manfaat penelitian baik akademis maupun praktis, serta sistematika penulisan yang merupakan garis besar kerangka penulisan. Kajian Pustaka

Berisi pengertian tentang konsep-konsep, pemikiran-pemikiran, serta teori-teori dan model-model komunikasi yang digunakan 
sebagai tolak ukur serta data penunjang untuk membantu peneliti agar mengetahui landasan dalam permasalahan yang berhubungan dengan pengembangan produk dan pasar Tabloid Nova. Kemudian peneliti juga mempunyai landasan berdasarkan teori-teori dan model-model yang tepat untuk memperkuat permasalahan yang akan diteliti lebih lanjut dalam penulisan tesis.

\section{Metodologi Penelitian}

Penjelasan tentang metodologi penelitian yang digunakan penulis dalam meneliti. Hal-hal yang terkandung dalam bab ini adalah mengenai informan yang dapat mendukung penelitian ini, metode pengumpulan data, metode analisis data, waktu, lokasi penelitian, teknik pengumpulan data, serta bagaimana teknik analisis data yang digunakan peneliti dalam menarik kesimpulan di akhir penelitian ini.

\section{Hasil Penelitian Analisis}

Pembahasan tentang penelitian yang mencakup gambaran umum tentang perusahaan yang bersangkutan dan mencakup sejarah singkat tentang perusahaan tersebut. Selain itu, bab ini juga menguraikan tentang hasil penelitian, analisis dan pembahasan mengenai diversivikasi produk digital dalam pengwmbangan pasar Tabloid Nova.

\section{Simpulan dan Saran}

Rangkuman dari seluruh penelitian, pembahasan kesimpulan yang berisi yang diambil dari hasil analisis dan pembahasan penelitian, serta saran yang merupakan masukan dari hasil penelitian yang dibuat oleh peneliti sehubungan dengan diversivikasi produk digital dalam pengembangan pasar Tabloid Nova.

\section{KAJIAN PUSTAKA}

Media massa merupakan media yang digunakan dalam penyampaian pesan dari komunikator kepada khalayak yang berjumlah besar secara serempak. Joseph
Turow dalam Media Today, bahwa media massa ada pada bagian personal dari semua kehidupan yang menghubungkan keadaan yang terjadi di dunia.

"Mass media materials speak to the most personal parts of our lives. They also connect us to the world beyond our private circumtances. As a result, mass media industries are a major force in society" (Turow, 2009)

Turow (2009) juga mengemukakan bahwa manusia mengadaptasi kebutuhannya akan media massa berupa empat cara, yakti enjoyment, companionship, surveilance, dan interpretation.

The desire for enjoyment, or personal pleasure, is a basic human urge. Watching a television program, studying the Bible, finishing a newspaper crossword puzzle, even reading an advertisement can bring this kind of gratification to many people (Turrow, 2009).

Enjoyment adalah bagaimana masyarakat melakukan keinginannya sesuai kesenangannya atau hal yang paling mendasar tentang apa yang disukai. Misalnya seperti menonton televisi, mempelajari kitab, menyelesaikan tekateki silang koran, bahkan membaca sebuah iklan yang ternyata bisa menjadi kepuasan bagi sebagian orang.

Sesuatu yang dianggap menyenangkan akan selalu menjadi pilihan setiap orang. Ketika seseorang merasa senang atau dapat menikmati sebuah media, maka media tersebut dianggap sudah dapat memenuhi kebutuhannya. Ketika sebuah media dipandang sebagai sebuah kesenangan, maka media itu sudah berhasil menjadi top of mind.

Menurut Rivers et al (2003), dalam pandangannya, masyarakat manusia bertahan berkat adanya komunikasi dan terus berkembang berkat adanya komunikasi. Dengan komunikasi, manusia melakukan berbagai penyusuaisan diri 
yang diperlukan, dan memenuhi berbagai kebutuhan dan tuntutan yang ada sehingga masyarakat manusia tidak bercerai-berai. Melalui komunikasi pula manusia mempertahankan institusi-institusi sosial berikut segenap nilai dan norma perilaku, tidak hanya dari hari ke hari, namun juga dari generasi ke generasi.

\section{Ekonomi dan Media Massa}

Tidak dapat dipungkiri bahwa faktor ekonomi dari sebuah bisnis media merupakan salah satu hal penting yang perlu diperhatikan untuk membangun kesuksesan media itu sendiri. Hal tersebut diungkapkan oleh Turow (2009) bahwa:

Success with the right audience is crucial if a mass media organization is to con- tinue operating. So let's look at the way mass media people think about, and conduct research on, the audiences for the content that their companies produce, distribute, exhibit, or finance (Turow, 2009).

Khalayak yang tepat merupakan

hal terpenting dalam menentukan kesuksesan dan kelangsungan sebuah media. Kita dapat mempelajari bagaimana cara khalayak berfikir, mempersiapkan sebuah penelitian untuk mengenal khalayak, dan memperhatikan khalayak guna menunjang produksi, distribusi, pameran, hingga keuangan.

\section{Media, Gender dan Identitas}

Antara media, gender dan identitas terdapat kaitan yang kuat, karena salah satu fungsi media sebagai alat komunikasi. Gender menjadi terkait ketika sebuah media mentargetkan pembacanya pada salah satu gender.

"Media and communications are a central elemet of modern life, whilst gender and sexuality remain at the core of how we think about our identities. With the media containing so many images of women and men and messages about men, women and sexuality today, it is highly unlikely that these ideas would have no impact on our own sense of identity. At the same time, though, it's just unlikely that the media has a direct and straightforward effect on its audiences" (Gauntlett, 2008).

Ketika media mengidentitaskan dirinya sebagai media untuk wanita, seketika pola komunikasi dan tampilan media tersebut betul-betul mengacu pada berbagai atribut wanita. Gambar, simbol, dan lainnya menunjukan bahwa media tersebut memiliki sasaran yang jelas. Sehingga berbagai identitas tersebut memberikan efek terhadap pembacanya.

Dalam perkembangannya, gender mulai dibuat setara, bahwa sebenarnya perempuan dan laki-laki adalah setara. Seperti yang disampaikan David Gauntlett, "If there is a 'battle of the sexes', who is winning nowadays? Women and men generally have equal rights - with a few exeptions within various laws, which we see being campaigned against and changed. The sexes today are generally thoght to be 'equal', to the extent that the cover of Time magazine wondered feminism was 'dead' in June 1998. There is even a noisy minority who argue that feminism has 'gone too far' and that it is now men who have the worst deal in society" (Gauntlett, 2008).

Identitas dapat dilihat melalui gender, apakah kita perempuan atau lakilaki. Perbedaan tersebut merupakan hal yang paling mendasar untuk menggambarkan sebuah identitas. Selain jenis kelamin, banyak orang yang mendiskusikan bahwa identitas itu termasuk umur, kelas sosial, pendidikan, latar belakang pendidikan dan lain-lain.

\section{Strategi Difersifikasi}

Difersifikasi memberi kesempatan bagi perusahaan untuk berkompetisi pada 
bidang yang terkait atau tidak terkait dengan bisnisnya.

Matrix Ansoff merupakan salah satu alat untuk membantu para pebisnis menentukan strategi yang tepat sesuai perkembangan pasar. Produk atau pasar yang pada Matrix Ansoff menunjukan bahwa sebuah bisnis tumbuh tergantung pada apakah sebuah pasar baru atau bisnis baru, atau bisnis dan pasar tersebut sudah ada sebelumnya.

Menurut survei terbaru dari 100 perusahaan terbesar di Amerika dari 1909 sampai dengan 1948, beberapa perusahaan mengalami stuck dengan produk tradisional mereka dan metode yang sudah kuno. Kesimpulan dari laporan tersebut adalah, "Tidak ada alasan untuk yakin itu semua yang di atas akan terus bertahan di sana kecuali mereka ikut berlomba melakukan inovasi dan ikut bersaing.

Terlihat bahwa Ansoff memetakan strategi apa yang harus dilakukan sebuah brand, berdasarkan kekuatan yang dimiliki brand tersebut. Semakin besar peluang bisnisnya, semakin besar pula resiko yang harus siap ditanggung oleh brand. Ada empat kategori utama dalam Matrix Ansoff yang dapat digunakan untuk memajukan suatu bisnis, berikut penjelasannya:

1. Penetrasi Pasar ( Pasar yang sudah ada, produk yang sudah ada)

Merupakan upaya untuk meningkatkan penjualan perusahaan tanpa menyimpang dari strategi asli baik secara pasar maupun secara produk. Perusahaan berusaha untuk meningkatkan kinerja bisnis baik dengan meningkatkan volume penjualan kepada pelanggan yang sekarang atau dengan mencari pelanggan baru untuk produk ini. Cara ini dapat berjalan dengan baik apabila perushaan mendapatkan pelanggan dari kompetitor atau menarik nonpengguna produk anda dengan menyakinkan melalui iklan atau promosi lainnya. Penetrasi pasar adalah cara paling berisiko untuk perusahaan yang ingin tumbuh.

2. Pengembangan Produk (Pasar yang sudah ada, produk yang baru)

Sebuah perusahaan mengembangkan produk yang memiliki karakteristik baru dan berbeda untuk melayani pasar yang sama.

Pada kenyataannya ketika perusahaan menciptakan produk baru, perusahaan bisa mendapatkan pelanggan baru untuk produk tersebut. Oleh karena itu, pengembangan produk baru dapat menjadi strategi pengembangan bisnis penting bagi perusahaan untuk tetap kompetitif.

3. Pengembangan pasar (pasar baru, produk yang sudah ada)

Strategi dimana perusahaan berusaha menyesuaikan produk yang sekarang (umumnya dengan beberapa modifikasi dalam produk karakteristik) untuk misi (pasar) yang baru.

Sebuah produk yang sudah mapan di pasar dapat mentargetkan produknya untuk segmen pelanggan yang berbeda, sebagai strategi untuk memperoleh pendapatan lebih bagi perusahaan. Pasar tidak perlu baru dalam dirinya sendiri, intinya adalah bahwa pasar baru untuk perusahaan.

4. Diversifikasi (Pasar baru, produk baru) Ini disebut keberangkatan simultan dari barisan produk saat ini terhadap struktur pasar saat ini. Hal ini mengakibatkan perusahaan memasuki pasar baru dimana itu tidak ada kehadiran sebelumnya. (http://foswiki.org/pub/Sandbox/Si miWiki/Strategies_for_diversificati on.pdfdiakses 26 July 2011, pukul 22.01)

Diversifikasi perlu dilakukan melihat kondisi pasar lama yang sudah stabil, namun tidak mengalami 
pertumbuhan yang signifikan. Menghadirkan produk baru dan menyasar pasar yang baru pula memiliki resiko bagi sebuah brand, namun apabila strategi tersebut berjalan dengan lancar, maka brand tersebut sukses memperluas pasarnya dengan pengembangan produk yang baru.

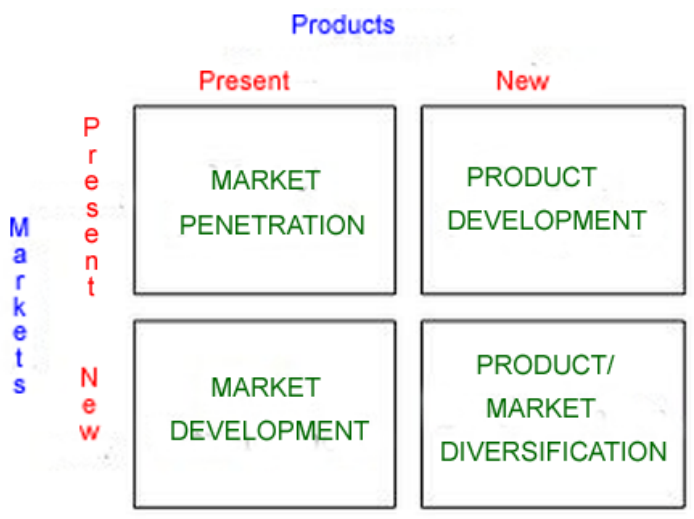

Gambar 3 Matrix Ansoff

http://www.ansoffmatrix.com/

diakses 22 Juli pukul 23.26

Matriks menggambarkan, bahwa elemen risiko meningkat lebih lanjut ketika strategi bergerak menjauh dari jumlah dikenal - produk yang sudah ada dan pasar yang sudah ada. Dengan demikian, pengembangan produk dan perluasan pasar biasanya melibatkan risiko lebih besar dari 'penetrasi '(produk yang ada dan pasar yang ada), dan diversifikasi (produk baru dan pasar baru) umumnya membawa risiko terbesar dari semua. Dalam karya aslinya, yang tidak menggunakan bentuk matriks, Igor Ansoff menekankan bahwa strategi diversifikasi berdiri terpisah dari tiga lainnya.(http://aslingtalks.com/marketingth eory/?tag=ansoff, diakses 22 July, 23.01)

Diversifikasi yang merupakan salah satu komponen dari matrix Ansoff, memiliki kaitan dengan pengembangan produk yang dilakukan tabloid Nova, dalam satu brand Nova membentuk sebuah produk baru yakni tabloidnova.com yang merupakan media versi digital, dengan sasaran atau pasar pembaca digital yang tidak terjangkau untuk membaca media cetak.

\section{METODOLOGI PENELITIAN}

Menurut Daymon dan Halloway (2005) peneliti kualitatif meneliti maksud, motivasi, dan pengalaman subjektif orangorang, dan menghargai bahwa orang melakukan sesuatu berdasarkan pada nilainilai yang mereka pegang, dan nilai-nilai tersebut ditunjukan pada hal yang dilakukan oleh orang lain.

Metode riset kualitatif cenderung menempatkan kata-kata sebagai unit analisis, sedangkan metode kuantitatif juga dihubungkan dengan sifat subjektif dan sebuah realitas sosial, maka metode ini memilii kemampuan yang baik untuk menghasilkan pemahaman dari perspektif stakeholder, sehingga memungkinkan peneliti untuk melihat berbagai hal sebagaimana dilihat oleh para pelakunya (stakeholder) (Daymon dan Hallaway, 2008). Paradigma yang sesuai dengan penelian ini adalah konstruktivisme sosial, dimana meneguhkan asumsi bahwa individu-individu selalu berusaha memahami dunia di mana mereka hidup dan bekerja. Mengembangkan maknamakna yang diarahkan pada objek-objek tertentu (Creswell, 2014).

Data primer yang digunakan dalam penelitian ini adalah wawancara mendalam (in depth interview) dan observasi. Sedangkan untuk Data sekunder untuk penelitian ini diperoleh melalui dokumen atau artikel lainnya yang diperoleh melalui buku-buku referensi, buku-buku perpustakaan, koran, situs internet, maupun informasi lain yang berhubungan dengan masalah yang diteliti.

Alasan penulis menggunakan metode penelitian kualitatif adalah untuk mengetahui lebih dalam adakah peluang keberhasilan produk digital untuk pengembangan pasar tabloid nova, di mata internal dan pembaca nova. 


\section{HASIL PENELITIAN DAN ANALISIS}

Sebagai tabloid yang usianya tidak muda, tentunya Nova memiliki kekuatan di mata pembacanya. Nova memiliki pembeda dan tabloid sejenisnya. Sebagai contoh apabila mengangkat topik selebritas, Nova membahas dari sisi yang berbeda, tidak serta-merta membahas gossip yang beredar di masyarakat, namum membahasnya dari fakta-fakta lain yang mendukung sehingga tidak terlihat sebagai issue belaka.

Kekuatan rubrik resep yang dimiliki Nova menjadi daya tarik pembaca menurut data yang menghitung topik yang paling diminati pembaca Nova. Ketika berbicara kekuatan, tidak hanya dari segi rubrik namun bagaimna Nova menjadi bagian dari habbit pembacanya. Menurut Gauntlett (2008), ketika media mengidentitaskan dirinya sebagai media untuk wanita, seketika pola komunikasi dan tampilan media tersebut betul-betul mengacu pada berbagai atribut wanita. Gambar, simbol, dan lainnya menunjukan bahwa media tersebut memiliki sasaran yang jelas. Sehingga berbagai identitas tersebut memberikan efek terhadap pembacanya. Andita mengungkapkan bahwa beliau membaca Nova disela-sela kesibukannya, di saat masak, sebelum tidur, dan kegiatan lainnya. Dalam salah satu poin garis besar tentang prinsip dan tujuan dari penggunaan teori uses and gratifications yang diungkapkan Bryant dan Zillman (2002), disebutkan bahwa to understand motives for media behavior; dalam hal ini Nova memberikan pengertian dan motivasi kepada pembacanya, bahwa Nova memiliki kebiasaan atau standar-standar dalam pembuatan berita atau konten yang ada di dalamnya. Konten Nova mudah diserap sehingga dapat di konsumsi di sela-sela kegiatan pembacanya. Namun konten tersebut tetap memiliki standar yang jelas, sebagai contoh rubrik resep, resep tersebut telah di uji di dapur Nova dan dengan bahan yang aman untuk di konsumsi.
Begitu besar efek yang diberikan Nova yang terbukti mampu menjadi media komunikasi bagi pembacanya melihat permintaan dan kebutuhan dari pembacanya pula.

\section{Strategi Nova}

Di tahun 2011 ini Nova berusaha agar tidak dikenal hanya sebagai sebuah tabloid, Nova ingin mengendorse para ibu yang tidak membaca tabloid, namun mereka masuk ke dalam segmentasi tabloid Nova. Oleh karena itu, Nova membuat platform lain melihat peluang yang ada di pasar. Maka muncul nova digital, mobil nova, komunitas nova, hingga program radio bersama Nova. Nova ingin menjadi sebuah brand yang menjual berbagai platform tersebut, hal tersebut diungkapkan brand manager tabloid Nova, Gatot Widhiyanto. Gatot menambahkan, apabila ada yang menanyakan siapakah pembaca Nova, pembaca Nova adalah semua yang mengkonsumsi Nova baik tabloid maupun digital. Intinya Nova mengembangkan komunitas dan merangkul lebih banyak konsumen.

Keempat platform utama yang dimiliki Nova akan terus dikembangkan melihat perkembangan dari pembaca Nova. Nova bergerak mengembangkan produknya berdasarkan riset yang dilakukan sebelumnya dan melihat psikologis para ibu di zamannya. Keempat platform yang sudah disebutkan sebelumnya memiliki fungsi saling melengkapi, apabila ibu bekerja yang tidak sempat membeli tabloid dapat mengakses di internet, ada sebagian ibu yang belum mengenal Nova ketika mobil Nova berkunjung, penasaran dengan isi tabloid Nova, lalu membeli tabloid Nova, hingga para Ibu pembaca Nova yang ingin mengisi waktu luangnya dengan kegiatan yang positif dan bermanfaat, dapat bergabung dengan klub Nova yang rutin melangsanakan kegiatan yang mengasah kreatifitas para ibu yang tidak jarang dapat menjadi bekal untuk membuka bisnis. 
Fenomena pembaca cetak yang kian menurun membuat redaksi Nova memformulasikan sesuatu agar dapat bertahan ditegah bisnis digital yang berkembang pesat. Menurut sebuah journal yang dibuat oleh Ahlers yang berjudul News Consumption and the New Electronic Media di tahun 2006 (http://www.jour.unr.edu/donica/Desktop/a hlers.pdf) dipaparkan bahwa media cetak dan berita televisi mulai mempertanyakan masa depan industri mereka. Eksekutif koran New York Times yang bertanya, "Apakah akan ada versi cetak mereka dalam sepuluh tahun kedepan?" Penyebab dinyatakan untuk alarm ancaman kompetitif Internet. Journal ini melihat pada pergeseran konsumsi berita dari media tradisional ke media online. Disimpulkan bahwa migrasi konsumen dari media tradisional ke media online belum sepenuhnya terjadi. Model segmentasi pelanggan adalah cara yang lebih tepat untuk melihat perilaku konsumsi media. Tidak ada satu tolak ukur yang cocok untuk semua pola konsumsi media. Beberapa pengguna akan online untuk memenuhi kebutuhan berita mereka, sebagian yang lain tidak meninggalkan media tradisional, dan yang lain akan merangkul semua media sebagai multichannel konsumen media. Hanya untuk kelompok kecil, media berita online akan bertindak sebagai pengganti bagi media berita tradisional. Bagi mayoritas, akan bertindak sebagai pelengkap.

Saat ini pemain media digital untuk wanita yang target pasarnya serupa dengan Nova memang belum terlalu banyak, beberapa kompetitor seperti hanyawanita.com dan perempuan.com. Namun menurut Rizky Muhammad selaku Brand Manager tabloidnova.com, kedua situs tersebut masih kurang all out dari segi kontennya. Nova yang telah lama mengelola sebuah tabloid, tentunya punya peluang lebih dari segi penulisan dan dalam mengelola pembaca. Sebagai pembaca baru tabloidnova.com pun, tentunya konsumen pernah mendengar tentang tabloid Nova (walaupun bukan pembaca tabloid Nova), sehingga pembaca lebih familiar dengan tabloidnova.com dibanding situs lainnya. Hal tersebut terbukti dari traffic tabloidnova.com yang paling tinggi di banding kompetitor sejenis lainnya.

Rizky juga mengemukakan bahwa di awal kemunculan tabloidnova.com, pihak redaksi benar-benar sporadis, artinya tabloidnova.com tidak memiliki strategi khusus, bahkan tabloidnova.com hanya memindahkan konten versi cetak ke dalam versi digital. Seiiring berjalannya waktu, pihak redaksi mulai mencari apa yang paling diminati oleh para pembaca media digital. Semakin lama, semakin terlihat bahwa segmentasi media jenis ini berbeda dari pendahulunya yaitu versi cetak. Hal tersebut diperkuat dengan survey tahunan yang dilakukan guna melihat background dan behaviour pembaca. Untuk konsumsi media digital, pembaca cenderung berumur lebih muda daripada pembaca media cetak, rata-rata bekerja, dan SESnya A-B. Kebutuhan seseorang untuk mengkonsumsi sebuah media digital juga berbeda dengan pembaca cetak, lebih instant dan singkat. Namun dari angle pemberitaan tetap menganggat topik yang sama dengan cetak. Sebagai contoh, apabila terjadi sebuah bencana, Nova tidak hanya memberitakan tentang bencananya, namun lebih mengupas sisi emosional wanitanya, diantaranya apa yang dilakukan para wanita disana pasca bencana. Hal tersebut dilakukan guna memberikan efek kognitif terhadap pembaca. Menurut Dominick (2009), efek kognitif membahas tentang bagaimana media massa dapat membantu khalayak daam mempelajari informasi yang bermanfaat dan mengembangkan keterampilan kognitifnya. Melalui media massa, kita memperoleh informasi tentang benda, orang atau tempat yang belum pernah kita kunjungi secara langsung.

Sejauh ini strategi yang dilakukan tabloidnova.com adalah memperkuat konten-konten yang paling diminati 
pembaca, dan mengemas itu semua dengan angle kewanitaan khas redaksi Nova. Ketika survey pembaca untuk tabloidnova.com membuktikan bahwa pembaca versi digital berbeda dengan versi cetak, maka redaksi tabloidnova.com menyesuaikan konten dengan behaviour pembaca digital. Sebagai contoh, ibu bekerja hanya memiliki waktu sedikit untuk membuka situs di luar pekerjaan, oleh karena itu versi digital dibuat sangat singkat dan padat, kalaupun beritanya panjang, maka akan di buat beberapa bagian, agar dapat di buka lain waktu oleh pembaca.

Sejauh ini strategi yang dilakukan Nova sangat cocok dengan para pembacanya, baik cetak maupun digital karena pembaca merasa cocok dengan konten Nova saat ini. Andita yang sudah lebih dari 15 tahun membaca Nova menyatakan perubahan Nova cetak selalu ke arah yang lebih positif, sangat mendidik para Ibu seusianya. Karena kecintaanya pada Nova, ketika sudah bermukim di Jakarta (sebelumnya bukan di Jakarta), Andita bergabung dengan Klub Nova yang di anggap dapat mengisi waktu luang Ibuibu seusianya. Nina,seorang ibu dengan usia yang lebih muda dan bekerja namun perlu mengetahui informasi mengenai wanita saat ini memilih tabloidnova.com sebagi salah satu sumber berita dan pengetahuan mengenai wanita dan keluarga karena Nina dapat mengakses tabloidnova.com seusai bekerja di kantor atau melalui smart phone apabila sedang tidak berada di depan komputer.

Salah satu poin yang diungkapkan oleh Bryant dan Zillman (2002) dalam garis besar dari prinsip dan tujuan teori uses and gratifications adalah to identify functions or consequences that follow from needs, motives, and behavior. Dalam penelitian ini dapat dilihat bagimana Nova mengidentifikasi fungsi dan konsekuensi dari kebutuhan, motivasi dan kebiasaan pembaca dalam memperoleh informasi. Sudah dibahas sebelumnya bahwa Nova sangat memperhatikan berbagai kebutuhan pembacanya, dengan berbagai konsekuensi, dan melihat media mana yang lebih nyaman digunakan untuk memperoleh informasi.

\section{Diversifikasi Produk Nova}

Pembaca Nova adalah semua orang yang berada diseluruh platform Nova. Walaupun dari versi print menurun, namun secara keseuruhan brand Nova, audience Nova naik tiga kali lipat dari sebelumnya, salah satunya karena hadirnya media digital. Ketika berbicara brand Nova, itu mencakup seluruh pembaca Nova dan berbagai platform yang dikembangkan oleh Nova. Terdapat berbagai perbedaan audience dari masing-masing platform tersebut. Rizky mengemukakan bahwa lokasi tempat tinggal juga mempengaruhi cara orang mengkonsumsi media. Para ahli berpendapat bahwa pengaruh media berdampak pada perubahan sosial dan psikologis. Seperti perubahan pesan dalam lingkungan sosial atau perubahan nilainilai budaya setelah pesan tersebut dimediasi. Sudah terjadi perubahan yang diakibatkan oleh faktor yang telah disebutkan sebelumnya (Nabi et al, 2009:13). Untuk tabloidnova.com berdasarkan data yang diperoleh dari google analytics, negara kedua terbesar setelah Indonesia yang membuka situs nova adalah USA, di ikuti dengan negaranegara di timur tengah, terlihat bahwa para wanita di luar Indonesia masih sangat peduli dengan berita dan pengetahuan yang dibutuhkan oleh wanita di negaranya. Sangat terlihat bahwa media digital memungkinkan diakses oleh seluruh wanita dibelahan dunia manapun.

Menurut Gatot, kemunculan Nova versi digital karena tuntutan zaman, kalau Nova tidak ambil bagian disana maka para pembaca digital atau pembaca cetak yang yang mulai beralih ke digital akan berusaha memenuhi kebutuhan tersebut dengan beralih ke media lain. Perpindahan versi cetak di awal kemunculan versi digital sudah dapat teratasi di tiga tahun belakangan ini, karena digital telah 
menemikan pasarnya dan mulai membuat versinya sendiri. Apabila tidak ada perbedaan antara versi cetak dan digital, maka versi digital dapat membunuh versi cetaknya.

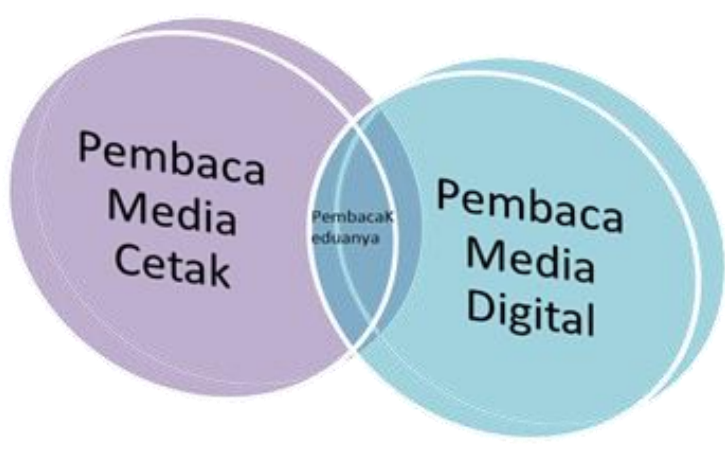

Gambar 4 Kurva Pembaca Nova (Sumber: Redaksi Nova)

Bila dilustrasikan, irisan yang terjadi antara pembaca cetak dan digital sangat kecil. Rizky memperkirakan hanya $10 \%$ pembaca cetak yang juga membaca digital, begitu pula sebaliknya. Hak tersebut menunjukan bahwa diversifikasi produk yang dilakukan Nova, memang benar mendatangkan para pembaca baru. Kriteria diversifikasi yakni membangun produk baru dan mendatangkan pasar baru dirasa tepat sasaran di dalam penelitian Nova ini.

Diversifikasi yang dilakukan oleh Nova mendapat tanggapan yang positif di pasar. Sebagai contoh, Nina seorang Ibu muda dan bekerja, sangat jarang membaca tabloid Nova dan tidak terfikir untuk berlangganan Nova, namun saat ini sudah menjadi pembaca Nova versi digital. Ibuibu generasi saat ini sudah banyak yang kekurangan waktu untuk membaca media cetak, mereka lebih senang dengan media digital yang dapat di akses di waktu luang, bahkan dengan perangkat mobile. Hal tersebut sesuai dengan data yang telah diperoleh sebelumnya bahwa pengguna internet wanita menggunakan handphone atau perangkat yang dapat dibawa secara mudah lainnya, untung membuka situs internet. Bahkan data tersebut juga mengungkapkan bahwa sejak dua tahun lalu pengguna internet mobile kaum Hawa meningkat 575 persen berdasarkan laporan dari 'The State of Mobile Web' yang dilansir oleh Opera Software. (http://hileud.com/hileudnews?title=Opera $\% 3 \mathrm{~A}+$ Pengguna+Internet+Mobile+Wanita + Naik\&id=271466 diakses 20 July pukul 09.03).

Dari sisi pengiklan, tingkat kepercayaan terhadap media digital juga semakin meningkat, walaupun ratenya masih kecil, namun terus meningkat. Menurut Rizky, klien yang memasang iklan mereka di media digital cenderung puas karena dapat di ukur dengan jelas. Dapat terlihat berapa jumlah pengunjung yang melihat iklan tersebut, apabila dalam bentukbanner, berapa banyak orang yang membuka banner tersebut, dan bentuk iklan kreatif lainnya di website, semua dapat terukur dengan jelas. Itulah perbedaan dari iklan di cetak dan digital. Untuk cetak hanya dapat di ukur dari oplag, tapi berapa orang yang betul-betul melihat iklan tersebut tidak pasti berapa jumlahnya.

Tanggapan pasar mengenai keberadaan tabloidnova.com sejauh ini sangat positif. Pembaca media digital dapat terpenuhi kebutuhannya dengan kehadiran tabloid Nova. Sangat terlihat perbedaan profil pembaca cetak dan digital, oleh karena itu penjelasan diversifikasi pada bab sebelumnya sudah membuktikan Nova dapat mennciptakan pasar baru dengan produk yang baru. Niny seorang ibu rumah tangga dan anggota klub Nova mengatakan, di usianya baru menginjak 36 tahun belum pernah sekalipun membuka tabloidnova.com, dari segi usia rata-rata pembaca digital yaitu 31 tahun, usia Niny tidak terlalu jauh, namun karena dia mengenal Nova versi cetak sejak awal, maka ia tetap setia dengan Nova versi cetak dan belum terfikir untuk mengakses atau bahkan berpindah ke Nova digital. Sangat terlihat antusias pasar terhadap media digital belum dapat membunuh para pembaca cetak. 
Selain tanggapan positif tentu ada kritik membangun, sebagai media yang masih berkembang, tabloidnova.com masih membutuhkan saran dan kritik dari pembacanya. Nina mengungkapkan bahwa tampilan dari tabloidnova.com desainnya kurang menarik dan terlihat kaku. Selain itu Nina berpendapat bahwa wanita menyukai gambar, dan Nova kurang melengkapi websitenya dengan gambar, kalaupun ada gambarnya berukuran kecil, sehingga alangkah baiknya gambar yang ada diperbesar dan diperbanyak agar lebih menarik.

Melihat tanggapan dari kedua produk Nova diatas, menjadi masukan bagi redaksi untuk mempertahannkan apa yang di anggap baik oleh pembaca, dan memproses kritik mengenai kekurangan pada media. Kritik tersebut dapat membuat produk Nova lebih baik dan di terima oleh pembacanya. Ada baiknya masukan tersebut juga dimasukan ke dalam survey pembaca, agar hasilnya lebih jelas dan terukur.

Menurut Dya, sebagai pengunjung tetap tabloidnova.com dalam satu tahun terakhir ini, sangat merasa puas, untuk wanita seusianya yaitu 28 tahun, tabloidnova.com sangat memenuhi kebutuhan pengetahuan dari sisi wanita. Ibu Dya juga suka mengikuti forum di tabloidnova.com, bahkan memiliki aplikasi Nova untuk smart phone agar lebih mudah mengakses tabloidnova.com. Menurut data dari redaksi, jumlah yang sudah mengunduh aplikasi Nova for BlackBerry mencapai 6.645 orang selama kurun waktu kurang dari 5 bulan. Hal tersebut juga menunjukan antusiasme dari para pembaca digital untuk dapat mengakses tabloidnova.com dari ponsel dan dapat dilakukan dimanapun pembaca berada. Nina menambahkan, dari segi konten tabloidnova.com sudah cukup bagus dan lengkap, hanya saja dari segi tampilan dirasa perlu untuk memperbaiki tata letak atau tampilan situs agar lebih menarik dengan tambahan gambar-gambar, karena para wanita akan sangat tertarik apabila tertera gambar yang bagus dan menggambarkan keindahan. Selain itu, karena pembacanya wanita dewasa, alangkah lebih baik memperbesar huruf agar pembaca lebih mudah membaca konten websitenya.

Para pengkonsumsi media digital cenderung aktif dan instan, kehadiran sosial media juga membantu promosi situs tabloidnova.com agar lebih dikenal masyarakat. Nova juga memiliki akun facebook dan twitter yang dapat membuka jalan seseorang untuk berkunjung ke tabloidnova.com. Selain itu, pihak klien yang bekerjasama dengan tabloidnova.com tidak jarang menggunakan nova untuk media pengumpulan quiz atau sayembara yang membuat masyarakat lebih aware dengan tabloidnova.com.

Menurut Rizky, setiap media memiliki kekurangan dan kelebihan masing-masing dan memiliki karakteristik yang berbeda-beda pula, sebagai sebuah brand yang hendak bekerjasama dengan sebuah media (promosi) sebaiknya tidak hanya menggunakan satu jenis media saja. Kuncinya adalah integrasi, aundience akan lebih mengingat sebuah promosi atau kampanye sebuah brand apabila brand tersebut menjangkau semua touchpoint. Menurut Research Multimedia Habit Readers in Indonesia - Kompas Gramedia tahun 2008, 80\% remaja dan dewasa di Indonesia membaca setidaknya lima media sebagai sumber informasi. Oleh karena itu berkembangnya bentuk media terjadi atas permintaan pembaca.

Rizky memberikan contoh untuk menunjukan pentingnya integrasi pada media dengan menunjuk pada maskapai penerbangan, beliau mengungkapkan mengenai touchpoint tadi, ketika sebuah brand hanya beriklan pada satu media, sebut saja billboard di jalan utama, tidak cukup. Hanya pada media televisi juga tidak cukup. Atau pada media cetak dan internet saja juga tidak cukup. Konsumen akan lebih peduli ketika melihat dan membaca iklan dari berbagai media. Ketika maskapai penerbangan hanya 
beriklan di televisi, ketika konsumen hendak melakukan pembelian via website, lalu muncul promosi lain di website tersebut, bisa jadi konsumen tersebut tertarik pada promo tersebut. Oleh karena itu, media manapun yang mungkin digunakan oleh konsumen, hendaknya diperhatikan oleh brand, sehingga brand dapat menjangkau konsumennya melalui berbagai media. Hal tersebut juga berlaku pada Nova, ketika hendak meyakinkan pengiklan, contoh diatas dapat dipakai sebagai perbandingan. Dari segi keseluruhan platform, Nova mendapat tanggapan positif dari pembacanya. Khusus untuk tabloidnova.com sejauh ini kehadirannya menunjukan pencapaian yang positif, baik dari pembaca dan pengiklan. Tabloidnova.com mampu mendatangkan pembaca baru dan mendatangkan pengiklan untuk produk digital, tentunya meningkatkan revenue Nova secara keseluruhan. Nova yang lahir di tahun 1988 dirasa mampu untuk melakukan diversifikasi yang dianggap strategi marketing paling berisiko bagi sebuah brand.

Strategi marketing yakni diversifikasi dianggap baik untuk produk yang sudah mapan. Matriks Ansoff menggambarkan, bahwa elemen resiko meningkat lebih lanjut ketika strategi bergerak menjauh dari jumlah dikenal produk yang sudah ada dan pasar yang sudah

ada

(http://aslingtalks.com/marketingtheory/?ta $\mathrm{g}=$ ansoff diakses 22 July, 23.01).

Sehingga ketika platform digital sudah stabil, hendaknya Nova dapat memikirkan strategi lain yang mampu menyaingi kesuksesan yang sudah diraih saat ini. Merujuk dari konstruksi konseptual yang digambarkan sebelumnya bahwa sejauh ini peluang keberhasilan Nova dalam melakukan diversifiikasi produk digital dalam pengembangan pasar tabloid Nova sangat besar.

\section{SIMPULAN}

Berdasarkan hasil analisis data dan pembahasan yang telah dilakukan dan di peroleh sebelumnya melalui narasumber dan data penunjang lainnya, maka simpulan yang dapat diambil untuk penelitian ini adalah sebagai berikut:

1. Strategi yang dilakukan oleh Nova sejauh ini cukup baik, keputusan Nova untuk mendiversifikasikan produknya sehingga terintegrasi dengan produk lain, mendapat tanggapan positif dari pembaca, dengan melihat tanggapan melalui survey pembaca juga dirasa tepat karena pasar media digital di Indonesia belum stabil. Setelah membaca karakteristik pembacanya, barulah dibuat konten-konten yang sesuai dengan behaviour pembacanya.

2. Diversifikasi dari Nova yang berawal dari produk media cetak dan membangun sebuah media digital dirasa tepat melihat pasar wanita yang masuk ke dalam target pembaca Nova sudah memasuki era digital dan menjadi pengguna internet, bahkan generasi ibu saat ini mulai meninggalkan media cetak, oleh karena itu diversifikasi yang dilakukan Nova sangat tepat untuk menjaring para ibu yang tidak membaca media cetak dan para ibu yang mulai meninggalkan media cetak.

3. Seiring berjalannya waktu dan diimbangi dengan jumlah pengguna Internet Indonesia yang meningkat, tabloidnova.com menunjukan kurva peningkatan yang positif baik dari segi pembaca dan pengiklan. Oleh karena itu, apabila tabloidnova.com dapat menjaga produknya dengan baik bahkan mengembangkan produknya sesuai permintaan pasar dan kemajuan teknologi, tabloidnova.com memiliki peluang keberjasilan yang 
tinggi bagi brand Nova secara keseluruhan.

\section{DAFTAR PUSTAKA}

1. Bryant, J., Zilman, D., Media Effect: Advances in Theory and Research. New Jersey: Lawrence Erlbaum Asocietes Inc, 2002.

2. Cheffee, S.H., Review of Is Anyone Resposible? How Television frames Political Issues, 1992.

3. Creswell, John W. Research design: pendekatan kualitatif kuantitatif dan mixed, Yogyakarta, 2014.

4. Daymone, Christine, and Immy Halloway. Qualitative Research Methods in Public Relations and Marketing Communication. New York: Taylor and Fransis e-Library, Routledge, 2005.

5. Dominick, Joseph, R. The Dynamic of Mass Communication. (2009) New York: McGraw-Hill.

6. Gauntlett, David. (2008) Media, Gender and Identity. New York: Routidge.

7. McLuhan, M., Undestanding Media: The Extentions of Men. London: MIT Press, 1964.

8. Rivers, William L Jay W Jensen dan Theodore Peterson, Media Massa dan Masyarakat Modern. Jakarta: Prenada Media, 2003.

9. Torow, J., Media Today: An Introduction to Mass Communication, New York: Houghton Mifflin Company, 2005.

10. Communication. New York: Houghton Mifflin Company.

11. http://jurnal.pdii.lipi.go.id/admin/jurna 1/13208268273.pdf, diakses 6 September 2011, pukul 21.37

12. http://users.uoa.gr/ atsaoussi/Nalebuff .pdf, diakses 6 September 2011, pukul 21.55

13. http://a67532.wordpress.com/2009/10/ 27/pengaruh-media-terhadapperkembangan-teknologi-komunikasi/ diakses tanggal 2 April 2011 pukul 20.30
14. http://www.sharingvision.biz/2011/02/ 07/grafik-eksponensial-surveipengguna-internet-indonesia-20062010/ diakses 3 July 2011 pukul 21.35

15. http://tekno.kompas.com/read/2011/01 /23/12503713/Perempuan.Lebih.Domi nan.di.Internet diakses 3 July 2011 pukul 21.56

16. http://hileud.com/hileudnews?title=Op era\%3A+Pengguna+Internet+Mobile+ Wanita+Naik\&id=271466 diakses 20 July pukul 09.03

17. http://teknologi.vivanews.com/news/re ad/212654-mayoritas-netterindonesia-akses-via-ponsel diakses 10 Juy 2011 pukul 20.34

18. http://tutor2u.net/business/strategy/ans off_matrix.htm $11 \mathrm{Jul} 22: 52$

19. http://foswiki.org/pub/Sandbox/Simi Wiki/Strategies_for_diversification.pd f diakses 26 July 2011, pukul 22.01

20. http://aslingtalks.com/marketingtheory /?tag=ansoff diakses 22 July pukul 23.01

21. http://www.ansoffmatrix.com/ diakses 22 July pukul 23.16

22. http://www.jour.unr.edu/donica/Deskt op/ahlers.pdf, diakses 6 September 2011, 21.44

23. Data Redaksi Nova

24. Data Pembaca Nova 2009

25. Data Nielsen - Dwisapta

26. Media Guide 2010 - Stand Up or Get Wasted - pppi 